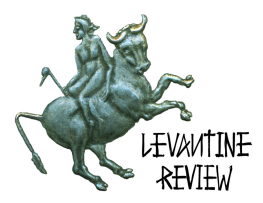

\title{
Identity and Peoples in History Speculating on Ancient Mediterranean Mysteries
}

Mordechai Nisan*

We are familiar with a philo-Semitic disposition characterizing a number of communities, including Phoenicians/Lebanese, Kabyles/Berbers, and Ismailis/Druze, raising the question of a historical foundation binding them all together. The ethnic threads began in the Galilee and Mount Lebanon and later conceivably wound themselves back there in the persona of Al-Muwahiddun [Unitarian] Druze. While DNA testing is a fascinating methodology to verify the similarity or identity of a shared gene pool among ostensibly disparate peoples, we will primarily pursue our inquiry using conventional historical materials, without however-at the end-avoiding the clues offered by modern science.

Our thesis seeks to substantiate an intuition, a reading of the contours of tales emanating from the eastern Mediterranean basin, the Levantine area, to Africa and Egypt, and returning to Israel and Lebanon. The story unfolds with ancient biblical tribes of Israel in the north of their country mixing with, or becoming Lebanese Phoenicians, travelling to North Africa-Tunisia, Algeria, and Libya in particularassimilating among Kabyle Berbers, later fusing with Shi'a Ismailis in the Maghreb, who would then migrate to Egypt, and during the Fatimid period evolve as the Druze. The latter would later flee Egypt and return to Lebanon-the place where their (biological) ancestors had once dwelt.

The original core group was composed of Hebrews/Jews, toward whom various communities evince affinity and identity today with the Jewish people and the state of Israel. Evidence from friends and acquaintances aroused my historical inquiry across continents and time-periods, offering a notion of the enigma of solidarity at hand. In recent years, I was privy to some startling personal disclosures. A young Lebanese woman divulged that in the cedars mountain are the original Israelites; a Kabyle from Algeria revealed the tale of four tribes, one being his own, claiming Jewish identity and that half the members of his family were Jewish; a friend from the Druze village Dalyat al-Carmel in Israel declared the Druze to be the true Jews. Could these self-revelations be sound oral evidence for an ancient bond among seemingly disparate peoples-people bound at the source to the Jewish people?

\section{Lebanese Phoenicians/Semites}




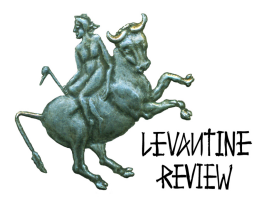

Jacob (Yaakov,) the third patriarch of the people of Israel, later known as 'Israel', awarded territory to the tribe of Zevulun which reached to Sidon in present-day Lebanon. In the wars to conquer the land, Joshua's forces chased the enemy to Sidon. A millennium and more later, around the beginning of the Christian era, the Talmud mentions a Jewish tanner in Sidon in connection with his family relations. ${ }^{1}$ Whether the man considered himself living in Israel or Lebanon, we do not know; but cognizant of the multiple connections between the two countries, either answer would be correct. Historical sources contend that Jewish communities lived in southern Lebanon until the end of the Second Temple period at the beginning of the Common Era. The Talmud refers also to Rabbi Yosef the Sidonite. ${ }^{2}$

Our tale and trek begin with the Bible. Although it was designated at least in part to be included within the national territory of the Promised Land, Lebanon was not conquered by Joshua. The tribe of Asher was destined to conquer the region approximate to Sidon, though he failed to expel the inhabitants; so that the Asheri settled among the Canaanite peoples of the land (Bk. Judg., Ch. 1.) Later Israelite tribes did in fact conquer in southern-central Lebanon. Canaanites lived in Mount Lebanon, and this was their identity before becoming known as "Phoenicians."

Noteworthy was King Hiram of Tyre, who "loved [King] David," providing workers and wood to his son King Solomon for building the Temple in Jerusalem (Bk. Sam. II, Ch. 5.) As a result, the Jewish Temple in Jerusalem [Bayt Ha-Miqdash] is called Bayt Yaar Ha-Levanon (House of the Lebanese Forest,) and Lebanon itself is referred to as "the forest of the Land of Israel" (Bk. Kgs I, Ch. 7.)

The father of Hiram was from the tribe of Naphtali, and his mother from the tribe of Dan; they lived in Tyre. Radak (the acronym of Rabbi David Kimhi,) a foremost medieval biblical commentator, relates that while King Solomon gave King Hiram 20 cities in the Galilee, the Tyrian king reciprocated by allocating to Solomon 20 cities in Lebanon to settle Israelites for the purpose of strengthening the alliance between the two monarchs and peoples. Thus, Israelites would be living in Lebanon, and Hiram sent sailors to work on behalf of Solomon.

Another way of connecting the two peoples is to attribute to both a Canaanite identity. The familial links between ancient Israel with Edom, Amon, and Moav, along with bearers of Israelite children by women from Haran, open up vistas of human blending in primeval Eastern history. King David later established an empire reaching into Damascus, and Solomon extended that dominion eastward to Tadmor (Palmyra) in the Syrian desert.

${ }^{1}$ Bab. Tal., Tractate Ketubot 77a.

${ }^{2}$ Bab. Tal., Tractate Ketubot $46 a$. 


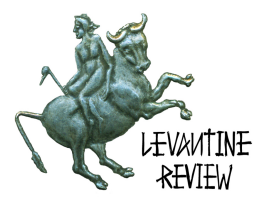

The mingling of the two peoples acquires further substantiation from the report that King Solomon was attracted to the Astarte [Esther] goddess of Sidon (Bk. Kgs. Ch. 11.) Furthermore, ninth century BC King Achav in Samaria, the northern kingdom of Israel, wedded Jezebel, daughter of Atbaal, the king of Sidon, and worshipped the god of Baal. Thereafter Atalya, Jezebel's daughter, married Yoram the king of Judea. Lebanese religious cults entangled Israelite kings, and the prophets of Israel berated the Phoenician pantheon that celebrated Tyrian and Sidonian gods. The fall of Lebanese commercial port-cities at the hands of Assyria and Babylon was not a mournful development in the eyes of Isaiah and Ezekiel.

The possible consequence of military operations and population movements northward and southward between Israel and Lebanon means that the Lebanese are really Israelites, or at the least, that the two peoples intermixed. This intimates that the Phoenicians were "Jews," perhaps pseudo-Jews, that is to say descendants from the tribes of Israel. Freud suggested that when Herodotus mentioned the Phoenicians, he most probably meant the Jews. ${ }^{3}$

Conceding fuzziness in names and geography, it seems that the northern Galilee reaches into southern Lebanon, and southern Lebanon overlaps the northern Galilee. Tyre, itself located in "Palestine" according to one geo-historic reading, 4 ruled in a politico-cultic fashion southward to Mount Carmel, and Phoenicians settled in Achziv and Akko (Acre). In the fifth-second centuries BC, a Tyrian colony was established in Ashkelon. Phoenician pottery findings from the tenth-eighth centuries were uncovered in Megiddo in the Jezreel Valley and at Hazor in the Galilee. ${ }^{5}$ Clearly very elastic definitions of countries and peoples point to the hybrid quality of Phoenician/Lebanese-Israelite/Hebrew relations.

An additional linkage concerns Tarsheesh, conventionally identified as Spain, but possibly denoting North Africa in the area of Algeria and Tunisia. Biblical commentary relates that both Lebanese ships (Kgs. I, Ch. 10) and ships from Judea (Kgs. I, Ch. 22) anchored at Tarsheesh for commercial purposes. Perhaps the Lebanese and the Judeans were partners, maybe competitors, in trade; alternatively they shared the sea lanes and economic pursuits. In the Temple in Jerusalem, Tyrian coins, engraved with the god Melqart, were common currency for public contributions.

${ }^{3}$ Sigmund Freud, Moses and Monotheism (New York: Vintage Books, 1939), p. 40.

${ }^{4}$ C. Autran, Phéniciens, Essai de Contribution A L'Histoire Antique De La Méditerranée, (Paris : Paul Geuthner, éditeur, 1920), p. 21.

${ }_{5}^{5}$ Maria Eugenia Aubet, The Phoenicians and the West: Politics, Colonies, and Trade, second edition (Cambridge: Cambridge University Press, 2001), Ch. 2. 


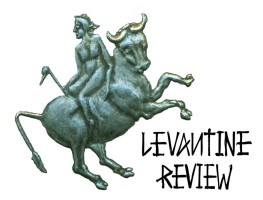

The ancient Israelites and Lebanese also shared the 22-letter alphabet, a writing system attributed to the Phoenician port-city of Byblos-a toponym with which the Greeks associated the word Bible. This Byblian alphabet-Byblia Grammata in Maurice Dunand's telling-was exceptionally similar to the ancient Hebrew script. The Lebanese and the Israelites' respective languages-Phoenician and Hebrewwere sister Semitic tongues with compelling correspondence in vocabulary, morphology, and syntax. ${ }^{6}$ Inscriptions from ancient Gebel appear in a Phoenician language intimately similar to biblical Hebrew. ${ }^{7}$ In the end, the modern Lebanese were to lose their ancient language, while the Jews preserved theirs in letters and renewed it as a modern spoken tongue.

\section{Carthaginian North Africans}

We follow the daring and enterprising Phoenicians approximately three thousand years ago, as noteworthy shipbuilders, traders, and colonizers, sailing off into the Mediterranean Sea, and further afield. Assyrian invasions of Lebanon and Israel catalyzed flight into the Mediterranean area, as Isaiah the prophet recorded (Ch. 22) the voyage of Sidonians to Cyprus (Kitiim,) yet warning that they would have to seek succor more distant yet from their beleaguered homeland. Samaria was conquered and Israelites took to the sea. During the millennium before Christianity, the Phoenicians established trading colonies from Cyprus and Rhodes, proximate to Lebanon in the eastern Mediterranean. Likewise they settled Crete, Malta, Sardinia, Italy, Sicily and Corsica, Spain and North Africa. They carried their wares (wheat and wine), their divinities (Adon, Baal, and Eshmon), and their Phoenician language; they shared their wisdom with the Greeks, opened bazaars, and mined in Spain. ${ }^{8}$ Jars, jewelry, candle-holders, coins, pendants, and statues attributed to the Phoenicians have been unearthed in ancient Kition, today's Larnaca in Cyprus, ${ }^{9}$ and all the way to Malaga in Spain. The Greek historian Thucydides mentions Phoenician merchant fleets and war vessels in the period of the Peloponnesian Wars in the fifth century BC; and over the centuries the Phoenicians fought against Greece and Rome in the regional and naval struggles for domination of the Mediterranean. Credited with founding Marseilles and Tangier among other cities, Phoenicians from Tyre, Sidon, and Byblos demonstrated an extraordinary ability, over hundreds of years, to

66 Zellig S. Harris, A Grammar of the Phoenician Language (New Haven, Ct.: American Oriental Society, 1936).

${ }^{7}$ Itzhak Avishur, Phoenician Inscriptions and the Bible [Hebrew], Part Two (Jerusalem: Rubinstein, 1979).

${ }^{8}$ See Ezekiel 27, v. 12.

${ }^{9}$ Source: The Larnaca District Museum (Cyprus). 


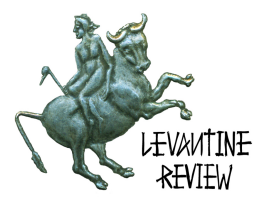

expand their presence and power in the face of nature's challenges on the sea, and their political clout overland.

A Jewish presence in the Mediterranean Sea basin is ancient and overlaps that of the Phoenicians. Jews lived in Malta, and the very name of the tiny island in the ancient Phoenician tongue as well as in the modern Lebanese vernacular and in both Aramaic and Hebrew, means "refuge" - which suggests both the danger of travel on the sea and finding safety in Malta. A site on the island of Corsica is known as the Hebrews Village ${ }^{10}$ while Spain in Greek was called Iberia, as the Iberian Peninsula is known today, possibly deriving from a Hebrew colony established in Phoenician times. In Catalonia there is the river Ebro. Meanwhile Phoenicians, who settled in Sardinia and Sicily, founded Cartagena (New Carthage) on the Spanish coast. The city of Cordoba (Kiriya Tova/the Good City) was founded by the Phoenicians and would later become an important Jewish center in the Common Era centuries. The Talmud relates that Resh Galuta, a local rabbinic authority, went from Corteva (Cordoba) to Hispania on the northern coast, and died there. ${ }^{11}$

The historic highlight of Phoenician expansion in the Mediterranean, its strategic axis for military and commercial activities, was the founding by imperial Tyre of colonial Carthage [Qarta Hadeshet] or New Town, in 841 BC near Tunis of the modern era. From there the Phoenicians fought for control of the sea lanes and trade against the Greeks and the Romans while extending their domination over Spain and their presence on the West African coast, as at Mogador, and crossing the Atlantic Ocean. At Carthage the Phoenicians, later known as Punics and their Phoenician language becoming Neo-Punic, farmed the lands in the area, chose leaders of merit and wealth who were, as described by Aristotle, "very successful in managing their political affairs, more so than most."12 Likewise the Carthaginian Phoenicians developed their military strength, and conducted their religious practices. After a series of the Punic Wars, with Rome capturing Sardinia and Corsica as well as Carthaginian possessions in Spain, the famous Punic general Hannibal was unable to overcome the Romans in Europe. In 146 BC, Scipio Africanus finally conquered and razed Carthage to the ground, fulfilling Cato's irrevocable refrain: "Carthage must be destroyed."

The Carthaginian Phoenicians worshipped the gods that they brought with them from the motherland: Baal Hammon, Melqart, Tanit, and others. The Canaanite god EL, 'God' in Hebrew, the son of Baal, and Reshef (in Hebrew 'Flash'), continued to

10 Corse-Israel French-language internet site, October 18, 2007.

11 Bab. Tal., Tractate Yevamot 115b.

12 Aristotle, The Politics (Middlesex: Penguin, 1966), Bk. II, Ch. 11; Bk. IV, Ch. 7. 


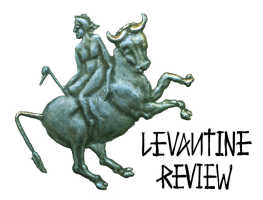

appear in religious rituals. ${ }^{13}$ Sanctuaries and statuettes were part of the physical appurtenances of worship. ${ }^{14}$ Of special import was Tophet for the cremation of children as an offering to the gods. This practice existed, denoted by the same name Tophet, not only in Carthage, but in Sardinia and Malta as well. Curiously enough, it also appeared in Israel as a religious deviation at the Ben Hinom valley in Jerusalem, as reported by the prophet Jeremiah (Ch. 19). In Gadir, which was founded by the Phoenicians on the west coast of Spain, and whose name is Semitic and means "fence" or "wall," an eternal flame burned as in the Temple in Tyre-and as in the Temple in Jerusalem. Images of God were absent in both famous temples, and in Gadir. Priests in Phoenician temples, in Cyprus, Malta, and elsewhere, naturally in Carthage, administered in bare feet, wearing white tunics, with shaven headsfeatures characteristic among kohanim (the priestly caste) in the Jerusalem temple. The Carthaginian religious vocabulary was analogous with biblical and post-biblical Hebrew, as in the use of the term Baal Hashamaïm (God of the Heavens).

The Hebraic character of Carthage was elucidated as born of a people possessing a single shared identity. ${ }^{15}$ Their origin-as Hebrews/Israelites and Lebanese/Phoenicians-was tied to the removal of the ancient Philistines, an obstacle on the eastern Mediterranean seaboard, thus cementing the alliance between the House of David and the House of Hiram. A covenant of brothers, stated Amos the prophet (Ch. 1), bound Tyre and Israel. Indeed, the cadre of Phoenician sailors likely included in their ranks men from the coastal seafaring tribes of Asher and Zevulun. ${ }^{16}$ This possibility is alluded to by one Talmudic source (Sanhedrin 94a,) with the eighth century BC Assyrian expulsion of Israelite tribes to Carthage, referred to as Afriqi.

In Carthage, situated astride the western Mediterranean, the common Hebraic language represented continuity in history. The earliest inscriptions date from the sixth century BC. In Phoenician and Aramaic, both akin to Hebrew, a votive statue derived its etymology from the root slmt, meaning "idol." 17 The Carthaginian judge was called sofet and analogous to the Hebrew shofet. Centuries later the Talmud referred in a halakhic discussion to a Rabbi Hanna (or Rabbi Acha) as a

13 Donald Harden, The Phoenicians (New York: Frederick A. Praeger, 1962), Chs. 5 \& 7.

14 G. Contenau (in Hebrew translation from the French): Phoenician Culture, 1949.

15 Nahum Slousch, La Civilisation Hébraique \& Phénicienne à Carthage (Tunis : Société Anonyme De L'Imprimerie Rapide, 1911).

${ }^{16}$ In the Bk. Of Hosea, Ch. 4, a hint of the possibility of Jews sold into slavery in the Mediterranean zone, perhaps as captives becoming sailing manpower.

17 Karel Jongeling, Handbook of Neo-Punic Inscriptions (Tubingen: Mohr Siebeck, 2008), p. 103. 


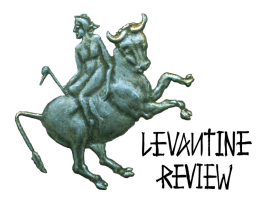

Carthaginian, either in North African Carthage or Nova Carthage in Spain. ${ }^{18}$ Jews and Phoenicians, ancestors and descendants, lived together and undoubtedly communicated in the same ancient Canaanite tongue. That the Phoenicians in Carthage originated from Canaan is strengthened by an interpretation of a rabbinic homiletic regarding "the sons of Africa [Tunisia] saying to the Jews that the land of Canaan [including Lebanon] is theirs" because, despite the Biblical inheritance to Ham, Shem son of Noah was granted Canaan. ${ }^{19}$ Shem is no less the Biblical patrilineal derivation for Abraham and the Hebrews.

\section{Kabyle Berbers (Amazighen)}

The migration of Phoenicians to North Africa launched a fascinating panorama of intriguing connections and relations among peoples. Of interest are Phoenicians and Jews, regardless of how we formulate their respective identities, but also the ancient Berber/Kabyle populations in the area. It is conjectured that the native population may have been of Canaanite origin, or more generally of protoMediterranean/Middle Eastern stock. ${ }^{20}$ The Berber language, it is suggested, belonged to the Semitic group, perhaps "Hebreo-African," but this is still subject to controversy. ${ }^{21}$ That Berbers spoke Punic-as the Carthaginian Phoenician tongue evolved on the Mediterranean coast-seems more than likely. In Tripolitania, western Libya, where Berbers lived, as in Jabal Nafusa until today, neo-Punic inscriptions were discovered and Berbers were reported to have served in the Carthaginian army in the fourth century BC. ${ }^{22}$ In fact, ancient Libyans are sometimes referred to as Berbers, or as Lybphoenicians, a mixed population arising over the centuries. Proof of Phoenician deities in Libya, sometimes known by their mythological Greek names-as Poseidon, the god of the sea, for Sidon-is but an etymological speculation for a word whose origin is unclear. The Lebanonization of North Africa was a development in ancient history.

Due to the primacy of Phoenicians in both countries, it is suggestive that the Hebrew place-names-Levanon (Lebanon) and $L \bar{v} v$ (Libya), both with a soft 'b' unlike their

\footnotetext{
18 Bab. Tal., Tractate Baba Kama 114a-b.

19 Breisheet Rabba 62, on Genesis, Ch. 9, verse 25 (Torah Temima commentary by Baruch HaLevi Epstein).

20 Internet video of Professor M. Salem Cheker, lecture in French at a conference on Origines des Amazighs (Berbères), March 1, 2012.

21 The Encyclopaedia of Islam, Volume I (Leiden: E.J. Brill, 1913), pp. 703-4. The connection between the Hebrew and Berber languages was proposed by A.G. Horon, East and West: A History of Canaan and the Land of the Hebrews [Kedem Ve-Arav in Hebrew] (Tel Aviv: Dvir, 2000).

22 B.H. Warmington, Carthage (Middlesex: Penguin, 1960), pp. 47, 65.
} 


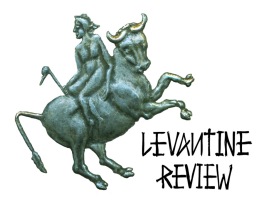

phonetic vocalization and letters in Arabic and English-could be etymologically connected. A captivating example of the use of the same word appearing as a name or part of a name in Lebanon and for place-names in Algeria is the word Bou, which seems like a short version for the Arabic Abou/Abu (father) or the Hebrew Aba. In Lebanon, until today, it designates an ancient non-Arabic toponym. In the Kabyle language, surviving in central-eastern Algeria and parts of Tunisia and Libya in particular, Bou serves as a tribal name, exemplified in Greater Kabylia for Ait [family] Bou Addou; as a name in the example of Bu Ziyan, a mid-nineteenth century hero of holy war against the French in the vicinity of Biskra, in the area of Djebel Aurès; ${ }^{23}$ and as a place-name as for the city of Borj Bou Arreridj. Inasmuch as the word Bou makes no evidential sense in the Kabyle language, this finding considerably supports the possibility that the word is an import from elsewhereperhaps from ancient Phoenicia/Lebanon. This single linguistic point indicates ancient Phoenician influence in Kabylia, of which even native Kabyles of today have no explanation or knowledge.

Phoenicians from the mountains and coast of Lebanon settled on the Mediterranean sea and in the North African mountain hinterland, where Berbers predominated; not only in the Aurès and Kabylia in Algeria, but also in parts of Libya. Two very distant connections between Phoenicians and Berbers indicate the geographic extent of Berber settlement. In one instance we learn of Hanno, the Phoenician maritime explorer in the fifth century BC meeting up with Berbers at Lixitae/Lixus (Morocco) on the West African coast who hosted and interpreted for him in his wide-flung travels. ${ }^{24}$ In another case, Phoenicians founded Qalama just east of Constantine, named by its founders Malaca (salt,) like Malaga in Spain, in eastern Algeria; now called Guelma near the Tunisian border, this town is located in eastern Numidia where there was an ancient Berber kingdom. A text found in Tunisia included both a Berber and Punic name as a bilingual Libyan-Punic inscription. Successive and overlapping layers of culture characterized the Phoenician-Berber eras.

On an early Egyptian hieroglyphics document, the dating of which is estimated at close to three thousand years BC, there is a sign signifying 'foreign land' for the

23 It has been suggested that the word Bou means a 'man'. On Bu Ziyan, see Julia A. Clancy-Smith, Rebel and Saint: Muslim Notables, Populist Protest, Colonial Encounters (Algeria and Tunis, 1800-1904), (Berkeley: University of California Press, 1997), Ch. 4.

${ }^{24}$ Harden, p. 176. On Hanno and Phoenician settlement on the Atlantic coast, see Duane W. Roller, Through the Pillars of Herakles: Greco-Roman Exploration of the Atlantic (New York: Routledge, 2006). 


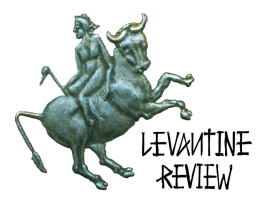

ancient Libyans. ${ }^{25}$ Could this be due to adventuresome Lebanese Phoenicians for whom Libya and its environs were indeed foreign terrain?

In the wider picture there was an ancient Phoenician colony just to the east of Libya in Egypt where the Libyans have been portrayed as enemy invaders. They are mentioned in the Bible during the tenth century BC period of the monarchy of Rehavam as soldiers in the Egyptian army invading Israel (Chron. II, Ch. 12). That foreign invaders of a country later become its loyal fighters is a conceivable possibility. Incidentally, Lake Qaroun, by that same name, is located in both southern Lebanon and in the Fayoum oasis, west of the Nile River not far from the Libyan plateau. Is this merely a coincidence or hints at intersecting mythic origins that began in Lebanon?

The Berbers, known as the free Imazighen, developed good relations with the Phoenician Carthaginians and intermarried. A Berber prince fell in love with a princess from Hannibal's family; and Berbers went to Spain to fight with his forces against the Romans. With Rome's victory and the destruction of Carthage, the Berbers came under the Roman Empire in North Africa. Thereafter Berbers adopted Christianity, and among their stalwart religious personalities was the Punicspeaking St. Augustine, whom they claim as one of their own, born in Souk Ahras in northeastern Algeria, dying in AD 430.

The Berber-Jewish connection is no less intriguing. That Berbers "Judaized," taking on a Jewish identity or recognizing a certain affinity with the Jews, in particular to avoid Islamization from the Arab conquest of the Maghreb beginning in the late seventh century, is known. ${ }^{26}$ That there were Berber Jews, who received their Judaism from Jews from Syria, is contended by the great medieval historian Ibn Khaldoun: "Among the Berber Jews one can identify the Djeraoua [or Jarawa], a tribe inhabiting the Aùres and [....] other Jewish tribes were the Nefouça, Berbers in Ifrikia [Tunisia-Libya area,] the Fendalaoua, the Behloula, the Ghiatha, and the Faza, Berbers of the distant Maghreb." Moreover, "an important part of the Berber population adhered to Judaism," even before the advent of Islam, is a resilient contemporary thesis as well. ${ }^{27}$ Berbers avoided a full acceptance of Islam and

25 Kabyle.com internet site (printed June 1, 2005).

${ }^{26}$ Haim Zeev Hirshberg, In the Shadow of Islam [in Hebrew] (Jerusalem: Youth Aliyah Dept., 1954), p. 53. According to Shari'a law, a Berber pagan would be forcibly converted to Islam or put to death, while a monotheistic Jew could retain his faith and live.

27 Marten Kossmann, "Loanwords in Tarifiyt: A Berber Language in Morocco," in Martin Haspelmath and Uri Tadmor, editors, Loanwords in the World's Languages: A Comparative Handbook (Mouton/The Hague: De Gruyter, 2009), Ch. 6, p. 195. 


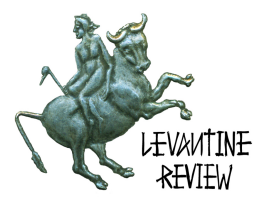

actually apostatized twelve times-and perhaps even more frequently because the report by Ibn Khaldoun was in the early fourteenth century. ${ }^{28}$ Perhaps some of the Berbers, often fighting the Muslims, were actually motivated in their resistance by their proud Jewish identity. It should be cited as well that there had been a Berber Christian community in Numidia, in the vicinity of Carthage and westward to Kabylia, prior to Islam's appearance and organized around the Donatist sect divorced from the Church of Rome. It is reported that some of its followers could speak only Punic. ${ }^{29}$ Again, this suggests evidence of either Phoenician origin or Phoenician mixing with Berber stock. The African Church dwindled after the Muslim conquest in North Africa, though in our times there is a nascent trend of conversion to Christianity among Kabyle Berbers.

Defining Berbers as Jews rings with drama in the mythic warrior persona of Queen Kahena who in the late seventh century led the resistance against the Arabs. The Berbers under her charge were ultimately defeated in AD 687. She was subsequently decapitated by the enemy, and the Berbers Islamized-at the latest by 719. They ultimately fought in Arab ranks to invade and conquer in Spain. This development could be interpreted as a return of Phoenicians-now Punic-mixed Berbers from/in North Africa. The commander of the Muslim invasion of the Iberian Peninsula was a Berber named Tarek ibn Ziad who, upon victory, settled Jews in Toledo. Over the centuries the martial freedom-loving Berbers would fight in the jihadic ranks of Islam, though at other times rising up in revolt against a variety of Arab regimes and rulers. This displayed Berber Kharijite credentials for renegade Muslim outsiders. ${ }^{30}$ The Warfajuma Berbers outraged Muslims by desecrating the Grand Mosque of Qairawan south of Tunis by keeping their horses there. ${ }^{31}$ Heresy lurked in Berber hearts, and folk practices persisted as with saint worship, marabout teachers, and sanctifying tombs. Yet many Berbers across North Africa, more in cities than the hinterlands, demonstrated a total acceptance of Islam,

28 Ibn Khaldoun, Histoire Des Berbères, Tome Premier (Paris : Librairie Orientaliste, 1925), pp. 208-9 for the quote, and pp. 28 and 198 on the apostasy of Berbers. Ibn Khaldoun was born of Andalusian parents in Tunis in 1332 and a Berber origin is proposed, though disputed. Certainly writing a large tome on the Berbers is itself a striking hint of his familial descent. On this question see Franz Rosenthal's introduction to Ibn Khaldūn, The Muqaddimah: An Introduction to History, I (London: Routledge \& Kegan Paul, 1958), xxxiv.

${ }^{29}$ L. R. Holme, The Extinction of the Christian Churches in North Africa (New York: Burnt Franklin, 1969), Ch. 8, and p. 251.

${ }^{30}$ Michael Brett, The Rise of the Fatimids (Leiden: Brill, 2001).

31 Jamil M. Abun-Nasr, A History of the Maghrib, second edition (Cambridge: Cambridge University Press, 1975), p. 74. 


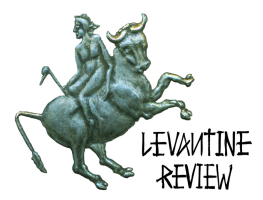

adopted Arabic, and wrote legal treatises and poetry in the holy language of the Koran.

The idea that Berbers were originally Jews or had been Jews, included the Zenata and Sinhaja tribes in Morocco and Spain, ${ }^{32}$ the Baragwata tribe claiming descent from the Israelite tribe of Shimon, ${ }^{33}$ the inhabitants of the Mzab in south-central Algeria where Jews lived in the town of Gardhaia-as possible descendants of Semitic Phoenicians-and eastern Berbers/Jews in Cyrenaica, in eastern Libya. ${ }^{34}$ For the last example there are sources claiming that Jews as cave-dwellers lived in Libya in ancient times, perhaps arriving after the Roman destruction of the Jerusalem Temple in AD 70, and also as "Jewish Bedouin" or Bahoutzim (outsiders), camel-riding fighters, in eastern Algeria and in the desert south of Tunis. ${ }^{35}$ Aside from encountering the presence and mixing of Phoenicians, Jews, and Berbers in North Africa, it is difficult to give a precise picture of the matrix of links among them. They are one of the same or much the same, even if different.

A Jew in Tripolitania (western Libya) reported in the early twentieth century that relations between Jews and Berbers were better than relations between Jews and Arabs. ${ }^{36}$ I learned of this social aspect from a Jewish woman I interviewed in 2005 who was born and had lived in the town of Tamarouft, located between the High Atlas and the Anti-Atlas in Morocco. She recalled relations of friendship and trust with the Berbers in the area. "Shloush" Jews lived safely with the Berbers and communicated in the Berber language (not in Moroccan Arabic.) The Berbers were saddened when the Jews left Tamarouft. When the woman's family stayed in Casablanca prior to departing for Israel, they experienced the same congeniality with the Berber storekeepers as when they lived in the mountain. ${ }^{37}$

\footnotetext{
32 Norman Roth, Jews, Visigoths and Muslims in Medieval Spain (Leiden: E.J. Brill, 1994), pp. 46-47.

33 Israel Friedlander, tr., The Heterodoxies of the Shiites According to Ibn Hazm, New Haven, 1909, p. 49.

${ }^{34}$ Information from Ronald L. Nagel in the Einstein Journal of Biological Medicine, 2004, 21, pp. 25-32.

35 G. Ben-Hanna, The Descendants of the 'Ten Tribes' - The Dispersed of Israel in the Global Diaspora [Hebrew], Tel Aviv: Yosef Shimoni, 1951), p. 43.

${ }^{36}$ Bat Ye'or, The Dhimmi: Jews and Christians under Islam (Cranbury, NJ: Associated University Presses, 1996), pp. 328-9.

37 I conducted three personal interviews with Zahava Edri, Jerusalem, March 13, 17, and 22, 2005.
} 


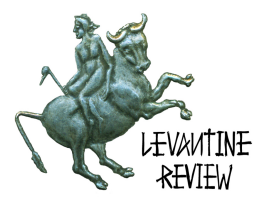

A similar but more poignant tale is told of Jews who lived in Tinghir, with one woman who moved to Israel claiming that "I'm 100\% Berber." ${ }^{38} \mathrm{~A}$ special affinity bound Jews and Berbers over centuries, perhaps millennia, with a shared fate of contending with the intimidating power of Arab rule and Islam. ${ }^{39}$ Berbers, in their convoluted and flexible religious adaptations over the centuries, adopted the freethinking heterodox Kharijite/Ibadi sectarian identity, distancing themselves from orthodox mainstream Islam. However, at other historical junctures they acted as fierce fundamentalist Muslims with a strict observance of Islamic strictures-as in the era of the Almoravids (Al-Murabitun) and Almohades (Al-Muwahiddun) during the eleventh-thirteenth centuries in the Maghreb and Spain.

Having probed the Jewish-Phoenician-Berber connections, we now turn to the next link in the chain of meshing and merging, with the appearance of Ismaili/Shiite forces in North Africa in the tenth century.

\section{Fatimid Ismailis}

A popular legend relates that Kutama Berber tribesmen on the hajj in Mecca about the year 900 brought back Abu Abd-Allah al-Shii home with them to North Africa and adopted his Ismaili faith, centered in Iraq and Iran. The name Ismail was drawn from the son of the sixth Shiite Alid Imam, and the Ismailis became known as the Seveners, distinguished from the larger Twelver Athna'ashariya group. Abu AbdAllah became the first Fatimid Caliph, negated the Sunni Baghdad-centered Arab Empire, as his Berber armies overran the rule of the Aghlabid governor in Qayrawan, Tunisia. Zanata and other tribesmen from the Sanhaja filled the military ranks. The Berber-Ismaili link was forged. The Ismaili missionary da'wa meanwhile spread from North Africa to Egypt and messianic expectations filled the religious air. Eastern Algeria, south of Constantine, and Tunisia became the geographic core of the Maghrebian Fatimid state.

Unlike the Sunni branch, the Shiites awaited a divinely-appointed leader who would validate the doctrine of the concealed truths, confirm antinomianism rather than the

38 Internet video on Les Judeo-Berbers Chleuhs [Jewish Imazighen], downloaded September 6, 2012.

${ }^{39}$ It is interesting to cite one contrary piece of evidence concerning Jewish-Berber relations, from a Kabyle poem recorded by a French researcher in the nineteenth century; see A. Hanoteau, Poésies Populaires De La Kabylie Du Jurjura (Paris: l'Imprimerie Impériale, 1867) p. 26. The reference is to Jewish cowardice, which is a customary negative image Muslims have of Jews. Kabylia rebelled against French colonialism in Algeria, but Jews welcomed it as protection from local Muslim Arab animosity. 


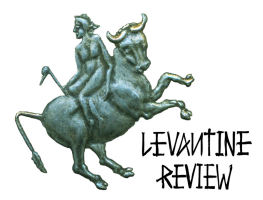

canonical (shari'a) law, and establish justice in history. Ubayd Allah al-Mahdi came from Salamiyya in Syria, initially went to Sijilmasa in Morocco (where there was a Jewish community,) and made his triumphant entry to Qayrawan in 910. This Mahdi filled his messianic role. He appointed Kutama chiefs over the towns in Ifriqiya (Tunis and surroundings.) After earlier failures, the Berber armies conquered Egypt in 969 and imposed Fatimid rule in the land of the Nile.40

The secret Shiite Ismaili cult, a rupture in the history of Islam, revered Greek philosophy more than they did the Islamic religion, and considered that reality is spiritual while rituals were nonsensical. Of significance was the philosophy of Egyptian-born Plotinus from the third century AD, whose Neoplatonism revolved around the One (the Mind) from whom the cosmos emanated and with whom man sought union. It may be said that in its heart of hearts Ismailism really wanted to destroy Islam, in the volatile spirit of its offshoots in the Ibadi/Carmathian heresies whose warriors killed pilgrims going to Mecca and stole the holy black stone from the Ka'ba. Carmathians, located in Bahrayn and southern Iraq, did not acknowledge the Egyptian-based Fatimid imamate, awaiting the return of their last true imam. Under the claim of representing the correct and authentic version of Islam, theyIsmaili Carmathians-concealed their goal of destroying it. Another variation of their ethos is that they were atheists. ${ }^{41}$ It was apparently their secret conviction that, with the imam's return, the law would be abolished. A more conventional and mainstream Ismaili view claims that the faith in all its varieties was defamed and misrepresented over the ages, by both Sunni Muslims and Christian Europe. ${ }^{42}$ Its esoteric doctrines, like the seven prophetic eras and the non-ritualized approach to Islam, were the backdrop to anti-Ismaili animosity.

In contrast was the Sunni conviction that the Shiites really opposed Islam within the framework of an exclusivist struggle between Sunni Arabs and Persian Shiites. The shared Berber and Fatimid hatred of Arabs and of orthodox legalist Islam from the early Arab caliphal period is central to the entire and complex picture that we are presenting. Caught among and threatened by a variety of Muslim forces-Sunnis, Shiites, Bedouins, and Ikhshidid "Turks"—-led also Jews to feel antipathy toward Islam. In Qayrawan and Fez, centers of Torah, the Jewish community was slaughtered.

${ }^{40}$ Founding the Fatimid State: The Rise of an Early Islamic Empire, an annotated English translation of al-Qadi al-Nu'man's Iftitah al-Da'wa by Hamid Haji (London: I.B. Tauris, 2006). ${ }^{41}$ Silvestre De Sacy, Exposé de la Religion Des Druzes, Paris, 1938, (Amsterdam : Adolf Hakkert, 1964), Introduction.

${ }^{42}$ Farhad Daftary, "Ismaili Studies: Antecedents and Modern Developments," ISIM Newsletter, 9/02, p. 37. 


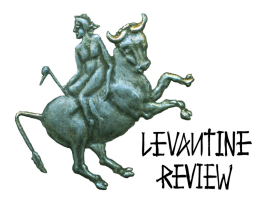

In the elliptical connections between Ismailism and Judaism, it was suggested that Ismailism actually assimilated Jewish ideas, what one author referred to as Jewish Batinism (the inner or mystical core of the religion.) ${ }^{43}$ Kabbalistic literature would surface and influence Jewish thought in later centuries.

A more substantive and substantiated link deals with Jewish conversion to Islam as a way to escape many of the ills and burdens endured under Fatimid rule. The legend was even promoted whereby the very lineage of the Fatimid dynasty derived from a Jewish blacksmith. Muslim rule over Jews, in Arabia, Greater Syria, and North Africa, had since the beginning of Islam made conversion a break-away route from despoliation and discrimination, insecurity and humiliation. Conversion freed the Jews from paying the impoverishing punitive poll-tax (jizya. $)^{44}$

But the tale of a Jewish connection really begins far earlier with the idea that Abdullah Ben-Saba or Ibn as-Saba, who was allegedly of Jewish origin, founding the Shiite school in Islam. This conspiratorial idea could be a Sunni invention to defame Shiism. The idea that the redemption depends upon the appearance of a messianic figure is common to Judaism and Shiism; the numbers 7 and 12 in Shiism, to identify the last imam, raise a resonance of a Jewish connection. It would be a subtle move were Jews to have surreptitiously promoted Shiism as a tactic to sow dissension and division within the ranks of Muslims, and thereby weaken the enemies of the Jews. Yaqub ibn Killis (930-991,) a Jew from Baghdad who had come to Cairo, adopted the Ismaili doctrine and became the vizier of the Fatimid state. He built the financial and administrative system and was favored by the caliphs. The Jews were wealthy and filled official positions and, in the late tenth century, there was apparently a wave of Jewish conversion to Ismailism, feigned or authentic as it might have been. ${ }^{45}$ Jews were either enticed to adopt Ismailism based on effective Fatimid propaganda, or sought to assure their welfare in a potentially erratic political and religious environment by joining the state religion and enjoying the material benefits available. Jews had converted under compulsion to Islam during Berber Almohad rule in Spain and the Maghreb, and then seemingly out of choice under Fatimid Ismaili rule in Egypt and Palestine.

${ }^{43}$ M. Paul Casanova, La Doctrine Secrète Des Fatimides D'Egypte (Le Caire : Imprimerie De L'Institut Français D'Archéologie Orientale, 1920), p. 35. ${ }^{44}$ Elinoar Bareket, "Personal Adversities of Jews during the Period of the Fatimid Wars in Eleventh Century Palestine," in Yaacov Lev, ed., War and Society in the Eastern Mediterranean, $7^{\text {th }}$-15 th Centuries (Leiden: E.J. Brill, 1997), Ch. 4, pp. 153162.

45 Joel L. Kraemer, Maimonides: The Life and World of one Civilization's Greatest Minds (New York: Doubleday, 2008), p. 158. 


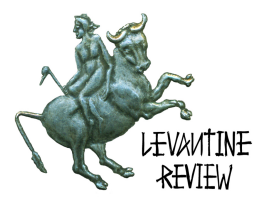

The Fatimid regime based in Sunni Egypt (909-1171) was often tolerant of others in a way that its sectarian character itself required tolerance from others. Berbers and Copts served in the Fatimid army, Jews and Christians manned government offices. Sunnis, though, were marginalized. In the latter part of the tenth century Fatimids and Carmathians clashed in Syria in the turmoil which struck the region. Muslims warred with the Byzantines in the constant religious scuffle. In 981 we learn of a Fatimid force in Palestine commanded by Manasseh a Jew. Things were astir, and an apocalypse was anticipated. ${ }^{46}$ Muslims, Christians, and Jews awaited some dramatic shift in the flow of history.

Meanwhile Berber and Turkish soldiers, and Jewish and Christian administrators and tax collectors, were pivotal in Fatimid/Shiite-ruled Egypt. Berbers were bound to their folk culture; Jews anxious about their dhimmi insecurity; and the Ismailis sought legitimacy for their sectarian heterodoxy with the founding of the Al Azhar Mosque complex in Cairo.

The sixth Fatimid imam/caliph, Hākim bi-Amr Allah, ascended the throne at the young age of eleven in 996 . His reign launched a religious revolution and messianic controversy, if not an apocalypse, that would provide our lengthy and bi-millennial journey that began in ancient Israel/Lebanon with its flight home.

\section{Druze/Bani Ma'aruf}

The Druze religion, whose name derived from an early preacher Muhammad Bin Ismail el-Darzi, was born in the spiritual womb of Ismailism and carried some of its ideas to an extreme and definitive conclusion. The propagandists and promoters of Hākim bi-Amr Allah's virtual divinity, as a new manifestation of God in history, and as a new and final emanation of the inexplicable and indescribable One, established the new faith as superseding the Sunni and Ismaili religions. The Druze doctrine of Da'wat al-Tawhid for the Bani Ma'aruf, as Unitarian believers and bearers of gnostic truths, led to the abandonment of the law, the elimination of the mosque, the nullification of the hajj, and the rejection of all Muslim communal prayers, fasts, or festivals. ${ }^{47}$ The Ismailis were radical, but the Druze heretics exited completely from Islam (as murtadd or khawarij). They committed the unforgiveable sin of apostasy the punishment of which is death according to the Islamic shari'a.

\footnotetext{
${ }^{46}$ Bernard Lewis, "An Apocalyptic Vision of Islamic History," Bulletin of the School of Oriental and African Studies, Vol. XIII, Part 2, 1950, p. 337.

47 Durūz (Druze), The Encyclopaedia of Islam, new ed., Vol. II, (Leiden: E.J. Brill, 1991), pp. 631-3.
} 


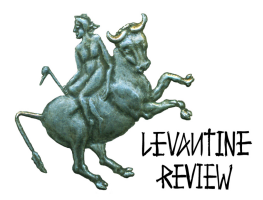

The spirit of the new sect reverberated audaciously when Hamza Bin Ali, its alleged chief founder and propagator, declared that he destroyed the two qiblas (directions of prayer): Mecca (for the Sunnis) and Karbela (for the Shiites.) For the new Druze there was only one religion in the world - and it was that of the Druze. ${ }^{48}$ In declaring al-Hākim an imam from on high, the Druze incidentally cast aspersion on the central tenet of Islam that Mohammad was the last prophet appointed by Heaven.

The first followers of the secessionist creed in Egypt during the period of the Fatimid state in 1017-1021 suffered persecution and grief (mihna) in the face of Islamic wrath. It is difficult to ascertain Druze ethnic origins: native Egyptian Coptic stock, Berbers, Arabs, Persians, Africans, Turks, Jews, or others. Al-Hākim appointed a Berber governor to Damascus. After he forbade Christian festivals and destroyed some churches, he then turned the churches into mosques; thereafter his inconsistencies and mysterious actions led to anti-Sunni decrees, and he finally discarded Islam. ${ }^{49}$ The Shiites were derided as polytheists because they venerate Ali (the first Shiite imam) and ascribe divinity to him. ${ }^{50}$ Under the $d a^{\prime} i$ Hamza Bin Ali, non-Muslims were later tolerated in this erratic spin of policies. In 1022 al-Hākim, who had a Christian mother, disappeared with the glow of ghayba emblematic of the hidden Shiite imams. Emissaries were sent to Syria/Lebanon, north to Aleppo, to propagate the faith. The initial "Egyptian" adherents fled to Wadi Taym in southern Lebanon in 1033.

The Druze doctrine soon acquired its definitive theological and philosophical principles. Of central importance was the dogma of reincarnation, which considered the soul eternal and its spiritual essence transferrable to a newly-born Druze. Practicing endogamy in marriage and intra-Druze soul movement, group cohesion and loyalty became the highest of values. The divinely-guided imam (or mahdi) possessed wisdom whose alleged eclectic sources, along with the Hebrew Bible, the New Testament, and the Koran, also encompassed classical Greek philosophy. ${ }^{51}$ But the secrecy that enveloped the new faith community, its inclination to dissimulate and delude, made it virtually impossible to gather accurate information on the deepest beliefs that defined the Druze. The wise uqqal men (and often women) of

\footnotetext{
${ }^{48}$ Henri Guys, La Nation Druse, orig. Paris 1863 (Amsterdam : APA-Philo Press, 1979).

${ }^{49}$ De Lacy O'Leary, A Short History of the Fatimid Khalifate (London: Kegan Paul/E.P. Dutton, 1923), Ch. 5.

${ }^{50}$ Silvestre De Sacy, p. 491.

${ }^{51}$ Nejla M. Abu-Izzedin, The Druzes: A New Study of their History, Faith, and Society (Leiden: E.J. Brill, 1984) Chs. 7- 8.
} 


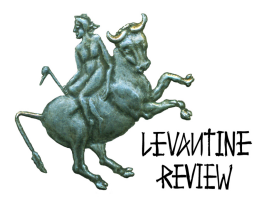

religion as seekers of truth and spirituality were the exclusive repositories of the hidden creed.

Pythagoras and Plato, two of the prominent Greek philosophers whose impact was apparently essential on the emerging religion, spent time in Egypt about a millennium and a half before the Druze surfaced in history there. Hellenic thought and Neoplatonism were vibrant in the Christian era and, as mentioned, Ismailism itself floated in such a metaphysical and theosophical atmosphere. The Druze doctrine of transmigration of souls, with the body seen as the tomb of the soul, was a central tenet in Pythagorean thought from the fifth century BC. The soul was ultimately free and indestructible. Pythagoras himself was considered a god or divine man, and his religious fraternity cultivated silence in its members whose selfconsciousness was one of veritable strangers in the world. They did not engage in politics, men and women were equal, and abstract thought-like mathematics-was prized over sense-perception. ${ }^{52}$ We can clearly identify the close similarity between the Pythagorean and Druze canon and conduct.

Plato's philosophy infuses the Druze creed: to wit, the notion of the soul as eternal, as discussed in the Phaedo Socratic dialogue, and the idea of promoting the equality of men and women in Laws (Chapter VII,) are foundational to Druzism. An overarching teaching by Plato's mentor Socrates in the Republic is the obligation of man to be good and temperate in behavior, and to contribute to the welfare of the state. Life is an illusion in this world and this dictum fills Druze faith. For the Greeks there was (perhaps) a God and gods; for the Druze there is God alone. Yet the intellectual and spiritual path travels the route of ancient gnostic and orphic schools of thought, of metempsychosis and hidden mysteries.

No less, the Druze rejection of Islam and ritual religion fits the Berber historical sensibility and practice. The special role of women in Berber history, in the case of Queen Kahena, is replicated among the Druze with the religion propagated in its initial days in Lebanon by Sitt Sārāh. The communities' respective flags display green, red, yellow, and blue colors; the Druze added white. These mountain dwellers demonstrated bravery and shrewdness. The Druze Muwahiddun, believers in the unity of God, were followed more than a century later, in 1150, by a Berber dynasty of the same name.

The connection between the Druze and the Jews is a rich tapestry rooted in history and mythology. Its beginnings in the desert near Egypt with the captivating biblical relationship between Moses and his father-in-law Yitro (Jethro,) known as Shu'eib

52 John Burnett, Early Greek Philosophy (Cleveland: The World Publishing Co., 1969), Ch. 2; and Bertrand Russell, A History of Western Philosophy (New York: Simon and Schuster, 1964), Part I, Ch. 3. 


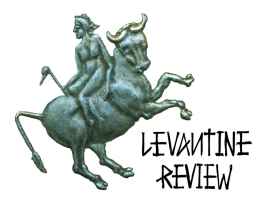

and the senior prophet of the Druze, unfold in a positive tie between the descendants of the two leaders. Legend has it that Yitro's progeny actually followed the religion of Israel, converted and lived in the tribal area of Judah; and that it is obligatory on the Jews to draw them near to Israel. ${ }^{53}$ We note, beyond the biblical instances of mutual assistance and friendship, the tale of a branch of Banu Judham to the south of Israel, kinsfolk of Shu'eib, itself a branch of Bani Wa'il (Joel/Yoel), reportedly inclined to Judaism. Some may have converted to Judaism before the appearance of Islam. ${ }^{54}$ An even more ancient legend that reflected Druze views was the idea that they are connected to the lost tribes of Israel. ${ }^{55}$

We are very much in the dark regarding the Jewish response to the Druze $d a^{\prime} w a$ in Egypt. It might be that Jews were involved from the outside in the religious revolution as an anti-Islamic démarche, or as an internal rebellion against the strict halacha and rituals of Judaism. A Druze epistle from those times berates the Jews for their practice of male circumcision and observance of the Sabbath day. ${ }^{56}$ The Druze intention was to validate the coming of Hākim bi-Amr Allah as seemingly foretold in the Torah, thus the Jews' rejection was berated as lacking spirituality and faith in God. The entire drama evokes the idea that the messianic discharge explodes in a moment of antinomian destruction of the law.

In the Bible both Joseph and Moses, each successful in his own way, were in Egypt. After an early revelation to Abraham had anticipated 400 years of slavery in Egypt for his descendants, the Israelites thereafter began their journey to the land of Canaan. It was 400 years on the Islamic calendar, between the Hegira of 622 to the disappearance of Al-Hākim in 1022, when the Druze broke the chains of persecution in Egypt and fled to freedom in Canaan/Lebanon.

\section{Returning Home}

Parallels among ancient Israelites/Judeans, Lebanese-Phoenicians, CarthaginianPunics, Kabyle/Berber Amazighen, and Druze, point to peoples differentiated from the broader forces in their territorial space. Seeking security above all else, these peoples have no inclination to impose their beliefs on others. The similarities shared

53 Bk. Judges, Ch. 4, verse 11 (RALBAG commentary); Bk. Samuel I, Ch. 27, verse 10; Bk. Samuel I, Ch. 22 (RADAK commentary).

${ }^{54}$ Moshe Gil, A History of Palestine, 634-1099, tr. (Cambridge: Cambridge University Press, 1992), Ch. 1, pp. 18-19.

${ }^{55}$ Nissim Dana, Ha-Druzim: Eida Ve-Masoret (The Druze: Community and Tradition) (Jerusalem: Ministry of Religions, 1974), p. 59, n. 9.

${ }_{56}$ Avraham Almakayas, The Druze Polemic Against Judaism (Hebrew), the Arabic Text, Jerusalem, The Hebrew University, Dec. 2009. 


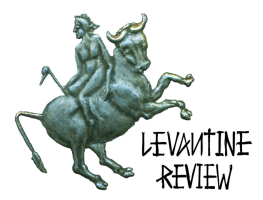

by these Mediterranean peoples may point to connections binding them from time immemorial until today: most specifically the Jews of Israel, the Maronite Christians of Lebanon, the Kabyle of Algeria, and the Druze in Israel and elsewhere. Elusive biological links and sociological traits conceivably bind them.

The political intimacy with Jews and Israel shown by the Maronites, Kabyles, and Druze in particular, demands an explanation. Not that there are no other communities who have shown sympathy for Jews and developed relationships with Israel; the Kurds of Iraq come to mind. However, the positive feelings toward Jews and Israel pointedly differentiate the three peoples mentioned above from the sweeping animosity Arabs/Muslims have directed against the Jews, Zionism, and Israel. In the case before us, shared overlapping interests clearly provide a major explanation-all the four peoples contending with Islam and Arabism; but we suspect and therefore searched for a more obscure and potent explanation that underpins this ancient coalition of 'minorities'-Jews/Israel, Maronites/Lebanese, Kabyles Amazigh, and Muwahiddun Druze.

The ancient Jewish people, enjoying sovereignty in its restored independent state of Israel, have been showered with admiration and friendship, and not only targeted by scandalous hatred and warfare. Before the founding of the state and since, Christian Lebanese, especially the Maronites, forged secret ties and sometimes public affiliations with Zionist leaders and Israel. Of note were the connections that evolved in the 1970s with Christians in south Lebanon and major Maronite personalities in Beirut. ${ }^{57}$ Kabyle sympathy for Jews and Israel was more discreet, but has been verified..$^{58}$ The Druze of Israel joined the pre-state struggle against the Arabs and thereafter became upstanding citizens and brave soldiers for the Jewish state. Some are self-declared Zionists no less fervent than the Jews for the state and homeland. ${ }^{9}$

Over many extended generations identities get blurred and peoples can no longer trace their ancestors. Religions and languages also disappear as the mixing of peoples and processes of assimilation erase salient cultural traits from memory. There are fascinating investigations and theories claiming to unravel ancient Jewish origins for a variety of peoples-from Tartars and Sogdians in Central Asia, ${ }^{60}$

${ }^{57}$ Ya'ir Ravid-Ravitz, Window to the Back Courtyard (Hebrew), (Yehud: Ofir, 2012). 58 Ferhat Mehenni, Algérie: la question kabyle (Paris : Éditions Michalon, 2004). Ch. 10.

${ }^{99}$ One such personality is Amal Nasereldeen, The Man of the Community and the Country (Hebrew), ed. Samih Natur, 2002.

60 David K. Law, From Samaria to Samarkand: The Ten Lost Tribes of Israel (Lanham, MD: University Press of America, 1992), pp. 143-7. 


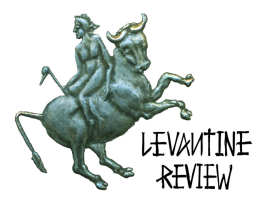

Pashtuns/Pathans in Afghanistan and the Indian sub-continent, ${ }^{61}$ and Arabs in Israel. ${ }^{62}$ There were also known instances in the Middle East, of Jews and Christians who became Muslims, some becoming Ismailis; of Druze in Lebanon adopting Christianity; and Berbers who became Jews. ${ }^{63}$ Jews from some villages in Palestine who disappeared from history may have adapted to the dominant religionChristianity, Islam or even the Druze faith. In Gush Halav (Jish) in the Upper Galilee, it is not unlikely that Jews from the Second Temple Period became Christians. It has been suggested that Muslims in Sakhnin in the Galilee, Yatta and Samo'a in the southern Hebron Hills, and in Beit Tsafafa in southern Jerusalem, derive from Jewish roots.

DNA genetic testing has raised the possibility of identifying ancient ancestry connections that could substantiate our historical analysis. Phoenicians, it has been propounded, traveled thousands of years ago and inhabited what was preColumbian America. A DNA study has suggested a link between them and the Cherokee tribe, and maybe other tribes, as evidence of Near Eastern/Mediterranean origin. This is then supplemented with a joint genetic signature for both Phoenicians and Jews. ${ }^{64}$

The Druze identity and ancestry remains a mystery. Genetic testing has been shown to be consistent with the oral tradition of Druze history and its closed religious narrative, practicing endogamy and consanguinity. Less clear is the ancestral genetic pool from which the Druze originated. It has been proposed that Druze ancestry includes Egyptian and Jewish elements. Positing that certain Galilee villages accepted the Druze religion in the initial $d a^{\prime} w a$ missionary period, it could be surmised that they were Jewish-inhabited in eleventh century Muslim-ruled Palestine. This for example is presumed for the village of Peki'in in Western Galilee, later referenced as a Druze village in the thirteenth century, whose historic native Jewish inhabitants were living there continuously for many hundreds of years-and

61 Eliyahu Avichail, The Tribes of Israel: The Lost and the Dispersed (Jerusalem: Amishav, 2005), pp. 75-143.

62 Tsvi Misinai, The Engagement: The Roots and Solution to the Problem in the Holy Land (Rehovot: Liad, 2007).

63 Two Jewish friends in Jerusalem, one from Morocco and the other from Algeria, shared the family account that their origin is from the Berbers.

64 Donald N. Yates. "Anomalous Mitochondrial DNA Lineages in the Cherokee," internet, submitted August 31, 2009. Other historians contest that there ever was a migration of Hebrews/Israelites or Phoenicians that made contact with native North Americans. See Deborah A. Bolnick et. al., "Civilizations Lost and Found: Fabricating History - Part Three: Real Messages in DNA," The Committee for Skeptical Inquiry, Vol. 36, No. 1 Jan/Feb, 2012 (internet). 


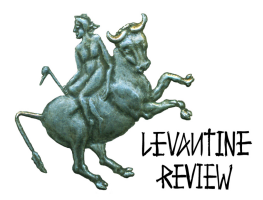

perhaps two thousand or more. ${ }^{65}$ Elusive though it may be is the possibility that all non-Jewish inhabitants in Peki'in over time-Druze, Christians, Muslims-were of Jewish/Hebrew racial origin. Recent genetic research revealed close affinity between Jews and Druze in Israel based on the ancient genetic pool in the Mediterranean/Middle East domain. ${ }^{66}$ They are genetic neighbors and not only social and political ones today. ${ }^{67}$ The Biblical basis for this finding is rendered reasonable but no less fantastic by the marriage of Moses with Tzipora, the daughter of Yitro/Nabi Shu'eib, and the relations that evolved between Yitro's kin, the Keini people, and the children of Israel over the centuries.

Let us review the stations on our journey whose travel-log is diffuse and whose evidence is fragmentary, but an intuitive sensibility has carried us along to mysterious paths of potential discovery.

It began in ancient times with Israel and Lebanon, neighboring Lebanese Phoenician and Israelite/Hebrew peoples, with their shared community of relations and language. The tribe of Asher even lived in Cyprus with its Phoenician presence. The population census in the time of King David included Tyre and Sidon to the north. 68 Even after the Babylonian exile in the sixth century BC, Hebrews from Zevulun and Asher remained in the northern Galilee/southern Lebanon terrain.

Our voyage continued across the Mediterranean Sea and to North Africa, with the Semitic-origin Carthaginian people in contact with Jews, and the possibility of their conversion to Judaism after the fall of Carthage. ${ }^{69}$ The Talmud records the phrase "from Tzur [Tyre] to Carteginia [probably the city on the Spanish coast and not Carthage in North Africa]," that reflects the Tyrian mother-city's excursions that Jews were aware of. 70

${ }^{65}$ Liran I. Shlush et.al., "The Druze: A Population Genetic Refugium of the Near East," internet, May 7, 2008. Regarding Jewish residence in Peki'in, the Babylonian Talmud Tractate Hagiga 3a records a story from the second or third century AD mentioning a Rabbi Yehoshua of Peki'in. The village is also cited in the Tosephta of Tractate Sota, Ch. 7.

${ }^{66}$ Makorrishon (Hebrew), August 20, 2010.

67 Gil Atzmon et. al., "Abraham's Children in the Genome Era: Major Jewish Diaspora Populations Comprise Distinct Genetic Clusters with Shared Middle Eastern Ancestry," The American Journal of Human Genetics, June 11, 2010, 86:6, 850-59. 68 Bk. of Samuel I, Ch. 24.

${ }^{69}$ Salo Wittmayer Baron, A Social and Religious History of the Jews, second ed. (New York: Columbia University Press, 1952), Vol. I, p. 374.

${ }^{70} \mathrm{Bab}$. Tal. Tractate Menachot 110a. 


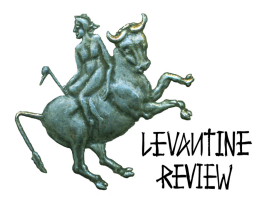

At the next station in our odyssey we met Kabyles (Amazghen) Berbers, some of whom converted to Judaism. Jews in Spain may have been Berber converts. Together with Jews in Egypt, Berbers played an important role in the establishment and security of the Fatimid Empire in North Africa.

In the following encounter we discussed the Ismaili Fatimids, whose religious doctrine was decidedly unorthodox, and some fusing with Jews was noted. Our next station in Egypt highlighted the appearance of the Druze religion for a people whose historiography included proximate biblical/Israelite associations that sprouted over the centuries. In the itinerary of travels of Benjamin of Tudela in the twelfth-century, it is reported that the Druze in Lebanon love the Jews. ${ }^{71}$ The flight of the Druze from Egypt leads them to northern Israel/Hermon/Syria, and Lebanon. But here we note that modern genetic research points to an African ancestral component in the Druze genome, and maybe here rests the Carthaginian and Berber/Amazighen link embracing and substantiating the unity of peoples that inspired and justifies our inquiry.

Lurking in these mysteries is the Druze "homeland" in Mount Lebanon with a possible connection with the ancient Phoenicians. Here is the enigma of Lebanese returning home. Both peoples sought isolationism and peace. War or jihad, as an offensive strategy, was not their preference or inherent inclination. Their belief in God was the bedrock of life and survival. But, again, this considerably characterized ancient Israel and the Jewish effort for managing life's challenges.

The wandering "Jews" returned home. Their multiple identities absorbed a rich variety of experiences and metamorphoses, but the inner core spirit never died. And we now can better speculate and perhaps understand the solidarity that brings together certain Lebanese, Kabyle, and Druze, with the modern Jews of Israel whose ancient ancestors provided their auspices for a life of freedom.

\section{* Mordechai Nisan is Lecturer Emeritus and scholar of Middle East Studies at the Rothberg International School of the Hebrew University of Jerusalem. He has researched and written extensively on Middle Eastern minorities, and}

71 The Itinerary of Benjamin of Tudela - Travels in the Middle Ages (Malibu, CA.: Joseph Simon/Pangloss Press, 1993), p. 78. 
Nisan / The Levantine Review Volume 4 Number 2 (Winter 2015)

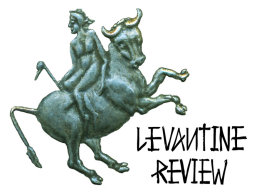

Lebanon. His most recent book on the subject, Politics and War in Lebanon, was published in May 2015. 